\title{
Sports Marketing Plan: An Alternative Framework for Sports Club
}

\author{
Edson Coutinho da Silva ${ }^{1} \&$ Alexandre Luzzi Las Casas $^{2}$ \\ ${ }^{1}$ Business School, University Centre of FEI, São Bernardo do Campo, São Paulo, Brazil \\ ${ }^{2}$ Business School, Pontifical Catholic University of São Paulo, São Paulo, Brazil \\ Correspondence: Edson Coutinho da Silva, Business School, University of Centre of FEI, São Bernardo do \\ Campo, São Paulo, Brazil. Tel: 55-11-4353-2900. E-mail: dr.edson.coutinho@gmail.com
}

\author{
Received: April 10, 2017 Accepted: June 16, 2017 Online Published: July 28, 2017 \\ doi:10.5539/ijms.v9n4p15 URL: http://doi.org/10.5539/ijms.v9n4p15
}

\begin{abstract}
The principles and tools of Sports Marketing represent the essential knowledge sports marketers require to a sports club develop strategies of events, matches and activities focused on customer-fans. However, for developing them, it is necessary a framework of Sports Marketing which comprises an arrange of processes for putting on practice the conception of marketing-oriented to customer-fans' needs. This paper aims to introduce an alternative Sports Marketing plan framework for sports marketers to plan, carry out as well as implement marketing strategies to create customer-fan-orientation philosophy of sports club. This study is part of a project which will provide some other empirical papers which will introduce the Sports Marketing principles on the perspectives of sports club from São Paulo, Brazil. This Sports Marketing Plan framework comprises three dimensions: (i) diagnosis of the situation, (ii) goals and fan's audience and (iii) Sports Marketing mix. The idea of producing this paper is orienting sport managers as well as Sports Marketing which studying, applying and researching this subject of improving the strategies for the planning, carrying out and assessing the Sports Marketing strategies and, also, for assisting sports clubs to professionalise its business management and improve its exchange process with their customer fans.
\end{abstract}

Keywords: sports marketing plan; sports marketing strategies; marketing of product

\section{Introduction}

Marketing focuses on the customer and the goal is attracting and satisfying them. Then, the goal and objective of marketing are to satisfy customers, determine what they want, what they are seeking for and sell it to them with profit. In other words, to offer the tangible or intangible product in the given place at the correct time, with the appropriate price, and using the skill people for carrying out service processes in the great performance which customer expected. For Clark (2011), in sport, marketing has been assumed that the original form of seeing the sports club, games and players have changed the exchange process and the relationship between sports club and fans, since the customer needs perspective requires considered. Clearly, the sports marketer must identify what needs and wants are being satisfied through the exchange process with fans. In this case, the process of exchange as the act of a fan obtaining a desired object-matches, events, activities, products, etc. - from a sports club by offering something - passion, energy, enthusiasm, excitement and money - in return. Thus, understanding fans as a customer is the first challenge; and identifying their needs of various segments of fans is another challenge inherent in the early phase of the marketing process. According to Collignon \& Sultan (2014) and KPMG Report (2014), obtaining this data and information will allow the sports good and/or service benefits to be prepared and communicated in such a way as to determine a certain sports club positioning. Having defined the assortment of the good as well as service characteristics in relation to needs and wants, the sports marketer moves on the (third) step of the process the exchange. Sports club should design an appropriated marketing mix to influence customer-fans to acquire their benefits, by means attendance or participation. Nevertheless, in relating to the marketing mix, it realises that the only traditional four Ps are incipient when a product is, actually, a service; then nine Ps are more suitable.

Thereby, sport and marketing, in several occasions, are still becoming familiarise to each other. Since the 1970s, most sports managers did not understand that the function of marketing was pertinent (Ratten, 2016). Nonetheless, as the sports perspective got increasingly competitive, sports managers started to fit their thinking. Several sports club have now created marketing sectors and many smaller sports clubs are opening to employ 
marketing skills to manage the get advantage of marketing in the designing process (The Future of Sports, 2015). This article aims to introduce a Sports Marketing plan framework for sports marketers to plan, carry out as well as implement marketing strategies to create customer-fan-orientation philosophy of sports club. This framework was conceived to comprise three levels: diagnosis of the situation, goals and fan's audience and marketing mix. These authors proposed this framework to assist sports marketers in improving new marketing strategies considering not only a mere fan, but a customer. Because fans fall in love and admire their sports club and team, i.e., it is up to the sports club creating conditions so that their fans consume products and services and want to be a fan member, through relationships which provide for both exclusive benefits. Therefore, this paper aims to contribute to the art of marketing applied to the sports club to foment more knowledge, discussion, and debates around the topic.

\section{Sports Marketing Overview}

The term "Sports Marketing" was first used in the United States by Advertising Age in 1978. Sports Marketing is an important aspect of global sports innovation as it is relevant to the business growth as well as survival. It observes that umpteen sports teams help with corporate sponsors around of the world through their global marketing campaigns (Shilbury, 2009). Chadwick \& Thwaites (2005) understand that Sports Marketing as a process by means which a contest with a doubtful result is arranged opening the chance for the concomitant fulfilment of objectives among sports customers-fans, sports businesses, participants and other associated people, bunches and organisations. From an international view, Sports Marketing is prescribed further as the chance for a company or an organisation to communicate their services in a sport-oriented context. This should contain the hiring the naming rights to a sports stadium, sponsoring players are offering clothing and sports equipment.

It notes that Sports Marketing has been developed to both the promotion of sports events and teams as well as the promotion of other products and services in relation to sports events. Mason (1999) has discussed the role of the sports products and customers-supporters. From a business perspective, the goal is to provide business companies with strategies to promote the sport or to promote products and services through sports events. Thus, the primary sports product can be both tangible as well as intangible in nature. Although this may be true, businesses and companies use sports as an alternative to achieve their customers and to sell their products and/or services. Indeed, Bernstein (2015) point out that Sports Marketing management needs to be able to market products to both sides of this relationship, i.e., an exchange process. Another challenge is that individuals often have both positive and negative personal views - or perceptions - with elements of the sports product. In a business context, the manufacturer is normally considered as the expert of a product. Nevertheless, when it comes to the sport, the customer believes they are the expert.

In general, Sports Marketing is characterised as a social and managerial process by which the sports managers look for obtaining what sporting companies require and desire through creating and exchanging products and benefits with people and other companies (Shilbury, 2009). Fullerton \& Merz (2008) introduce another view, that Sports Marketing is the activity of planning and implementing processes for production, pricing, promotion and distribution of sports products to satisfy the needs or desires of customers to achieve the organisation's results. For Smith \& Westerbeek (2003), Sports Marketing must have focused on Marketing of Sports products as a basis for the creation of revenue for sport organisations while designing marketing plans that will lead for potentialising of revenues accruing to a sport organisation; and they still include Marketing through Sports referring to Sports clubs such players, teams and programs the organisation's marketing plan. In this context, two distinct streams exist within the broad concept of Sports Marketing: Marketing of Sports and Marketing Through Sports.

Marketing of Sports includes marketing sporting events and equipment to fans and participants. This sort of Sports Marketing is intrinsic in the introduction of new sports such as action sports and innovative new sports products (Fullerton \& Merz, 2008). Marketing through sport is considered sport as communications media or a sponsorship alternative for organisations that market customers, and to a lesser extent, enterprise products. While Marketing of Sports is an approach to marketing activities and processes to market goods as well as services toward to sports fans and spectators; Marketing through Sports means the promotion of non-sporting products and/or services at sporting events and the use of players to support non-sport products and/or services (Fullerton \& Merz, 2008; Ratten \& Ratten, 2011; Rundh \& Gottfridsson, 2015; Shilbury, 2009). Thereby, Sports Marketing consists of all activities designed to meet needs and wants of sports customers through exchange processes. Sports Marketing has designed two major thrusts: First, the Marketing of Sports products and/or services towards to fans of the sport. Second, the marketing of other customer and enterprise products or services considering sports promotions (Mason, 1999). 
By the large, professionals need to know three different dimensions of Sports Marketing: (i) advertising in relation to sport and sport associations such the Olympics, Sports Leagues-as British Premier League, etc.; which can be labelled "Marketing of Sports"; (ii) promotion of sport in relation to the public to increase the participation at sport events or other kinds of arrangements, it means, product which is created by professional sports leagues. Several means are used, such as sponsorships for the promotion of teams or athletes, TV and radio advertisement, advertisement in relation to the sports event and celebrations (Shilbury \& Rentschler, 2007). For Fullerton \& Merz (2008), other means are billboards in the streets and promotions and publicity during major sporting events; (iii) promoting of products in relation to sports events such as "Marketing Through Sports". In this sponsorship plays an important role. Sponsorship in relation to sports events is also an area that has interested because a sponsorship is a powerful device for communicating with spectators at sports events and fans watching events on TV at home. Therefore, the marketing of sports products may provoke a positive idea through the inclusion of the sponsorship of an admirable sports property take into account an appropriate communication plan (Collignon \& Sultan, 2014; Rundh \& Gottfridsson, 2015).

Sports Marketing capitalises on the popularity of sports. Sports marketers research the demographics and consumption habits of fans to get more revenues on the items customers-fans obtain or buy the good and/or services related to sporting events. The price fans are willing to afford for a ticket depends upon the emergence of the market, the national (or international) relevance of the match, the talent of the involved players, and the competition linked with the league or tournament. Fans are usually buying team identified clothing or equipment and for the costs of food and travel to and from a match. The goal of Sports Marketing is to apply, then suitable marketing mix to achieve customers-fans meet their needs while providing a revenue (Shilbury \& Rentschler, 2007). In summary, marketing-driven strategies enable to the sport to respond better to the fans/customers' needs and to reach even more fans. The sport has turned in to be entertainment and economic success in becoming a more central element in sport. The sports business has also become increasingly more customer-oriented.

\section{Sports Marketing Plan: Proposal of a Model}

Before addressing what, a Sports Marketing Plan encompasses, it is helpful to approach the structure hierarchical of Sports Marketing concept. There are four levels, which need be considered. At the most fundamental level, Sports Marketing embraces a general philosophy or a set of beliefs about marketing performance in an organisation. It is not only sports marketers and marketing sector of sports entity that are responsible for marketing activities and processes. A marketing philosophy means putting the needs and wants of a customer-fan in the centre of the decision-making (Silva \& Mazzon, 2016). It is relevant to include that the needs of the customer-fans must complement the objectives of the sports entities. In business, the objective is usually to win or attract attention to the sports entity. Marketing principles involve generating a win-win exchange process for both the sports club and customer-fans, but it realises that no one will win if customer-fans' expectation is not achieved (Blumrodt, Desbordes \& Bodin, 2013). 


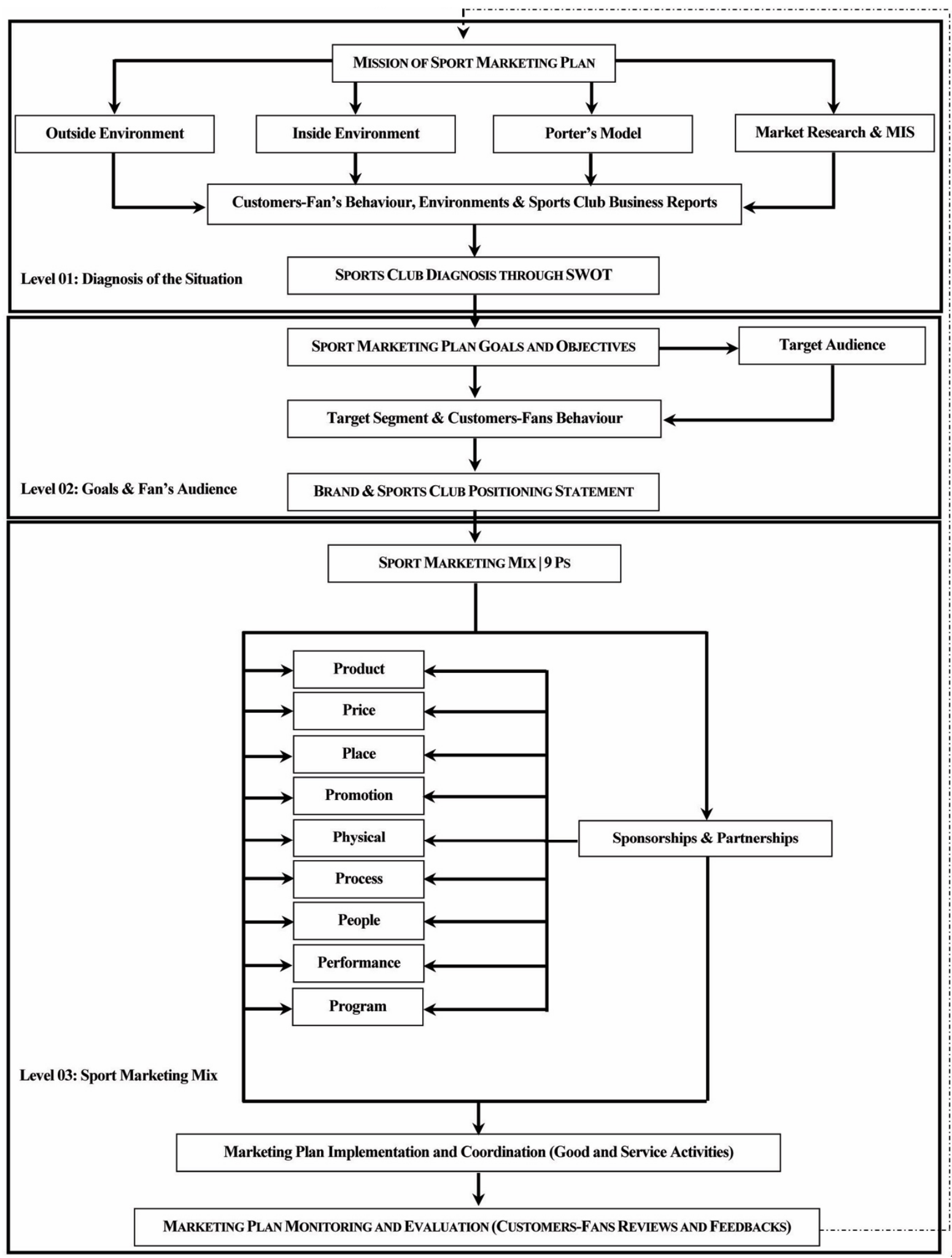

Figure 1. Sports marketing plan

Source: authors.

At a second level, Sports Marketing involves processes and/or steps. It is a process because it requires several activities as well as stages, required to find opportunities, devise a strategy, plan the tactics, and implement and evaluate a Sports Marketing Plan. These processes are a common property of Sports Marketing and feature as 
the structural framework. At the third level, Sports Marketing has been described as a set of principles, since it adopts concepts that provide specific guidance to those undertaking Sports Marketing tasks. In other words, principles aim to provide clear guidance as to how the process of Sports Marketing can be used in practice. Finally, at the most operational level, Sports Marketing implements the arrange of tools, which are analytical devices and given activities applied in day-to-day practices. Then, Sports Marketing may be summarised as a philosophy based on some commercial strategies which involve some processes, a set of general rules and guidelines as well as tools for managing customer relationship (Mastermann, 2004; Maltese \& Danglade, 2014).

In order to assist to "art" of Sports Marketing as well as figure out new opportunities to undertake new innovations and solutions in the sport arena, these authors propose a Sports Marketing Plan framework, for understanding the step-by-step required to set up sport products, services and events in view to respond the sport customer-fans' claims in terms of efficient, effective and marketing orientation from a sports club. This framework has several processes which are grouped into three levels: (i) diagnosis: whose function is a set of activities to research, collect and analyse data from external and internal environments, factors which affecting the fan's behaviour and SWOT (Strong, Weakness, Opportunity and Threat) analyses to diagnosis the real situation; (ii) Fans: it encompasses the goals and objects of marketing plan, selecting and defining the target customer-fans audience and positioning the value position and brand on the market, which it will guide the Sports Marketing strategies; (iii) Sports Marketing Mix: the tools that will provide and ensure mechanisms to measure, analysis and asses of results as well as sponsorship and partners, in which they will sponsor, develop and work together to the extent of the sports club team (Mastermann, 2004; Shilbury, 2009). In this next subtopic, these authors will explain all the process on the three levels to develop a Sports Marketing Plan, see figure 1.

\subsection{Diagnosis of the Situation}

The first process is the mission of Sports Marketing Plan. A mission statement describes directions for the sports club, determining and explaining its meaning and reason for existence. To be unique as well as singular, a mission statement should distinctly answer "What is our market plan?". The mission statement must be clear and concise in view to assist in produce common sense about the purpose as well as guide decision-making and resources allocation in the future. In this sense, the mission statement of the Sports Marketing Plan must include: answering the interest of the sports club; specifying the needs that the sports club's focus on; incorporating the values of sponsorship; describing and identifying the advantage of the sports club; introducing the real objective and trend of sports club in long term; and defining the sports club craves in the long term. Therefore, the powerful mission of sports club requires a set of elements: (i) strategic purpose, a set of sports goals of benefits designed by sport marketers; (ii) organisation principles, approaching moral and ethical issues to toward the Sports Marketing Plan; (iii) valuable competencies, expressing fulfilment; (iv) target segment, through several activities and processes customer-fan oriented; (v) positioning, the image related to benefits of sports club. Hence, the mission statement is an abstraction of strategic vision (Silva \& Mazzon, 2016).

The second and third processes refer to outside and inside environment. Silva \& Mazzon (2016) state that the environmental factors (or variables) requiring consideration, which are the forces that affect sports club indirectly. Such forces influence and impact of the sports marketers' decision-making in towards to plan, develop and maintain marketing activities driven to the target audience. Outside environment consists of farthest variables of the sports club, which are represented by technology, demographic and social trends, economic issues, political legislation, natural and sustainable concerns. Inside environment is closest variables, such: resources, competencies, capacity of providing services, customer-oriented culture of the sports club, departments performance, suppliers and outsourcing, sponsorships, marketing channels (point of sale, financial companies, communication companies) and publics (see figure 2). Sports marketers have chances to interact, handle and take some decisions in inside environment. Having deep knowledge about outside and inside environments besides markets research allow for sporting marketers mitigate risks eventual with purpose to improve efficient and effective related to processes and decision-making managed for sport marketers, in view to address solution to customer-fans.

The fourth process involves the sports club competition, based on Porter's competitive forces model. For Mastermann (2004), Shilbury (2009) and Kosík (2011), Porter's model describes five forces that sport marketers should review when examining competition and the attractiveness lined up for a sports club: (i) intensity of competition between existing sports clubs for winning a league; (ii) bargaining power of buyers refer to process to bargain products, services and events to fans, spectators, members, sponsors, etc; (iii) threats of substitute products means other sort of product, services or events from competitors (at same area or not) which met the same needs or perform the same functions on customer view, as cinema, theatre performances, music concert, etc; (iv) bargaining power of suppliers represent the bargain process to hire new talent players and sponsorship or 
partner for designing, producing and selling sports club products, services and events; (v) threat of new entrants are other sports clubs which start to be part of the league, at which may change the sports club position in the sport market in terms of ticketing, products, services, events and customer-fans' potential. Professional leagues for football will be used to illustrate the applicability of Porter's model, see figure 3 . This model in this instance assumes that a professional sports league can be competitive pressures of the entertainment and leisure sectors.

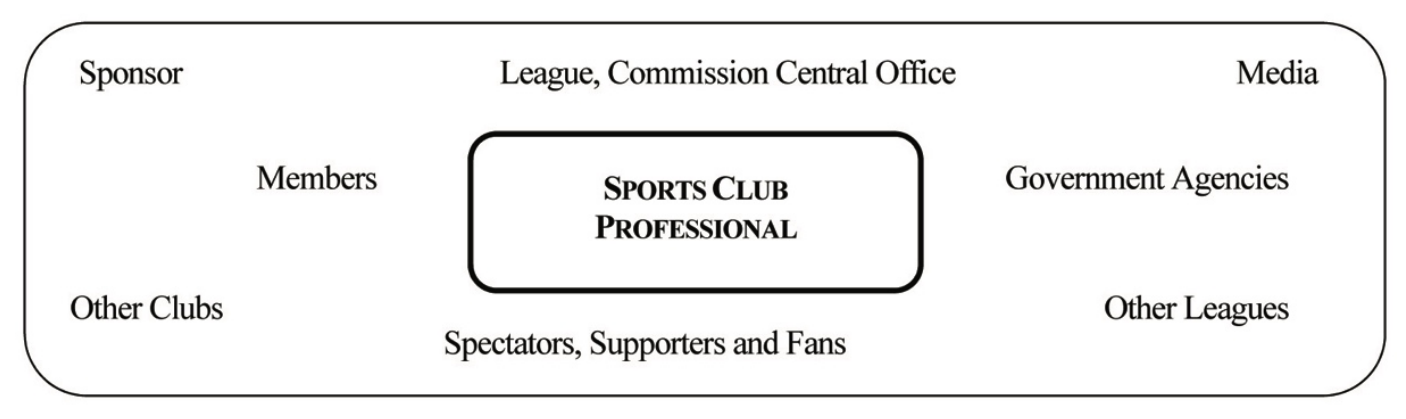

Figure 2. Sports club stakeholders

Source: Shilbury (2009).

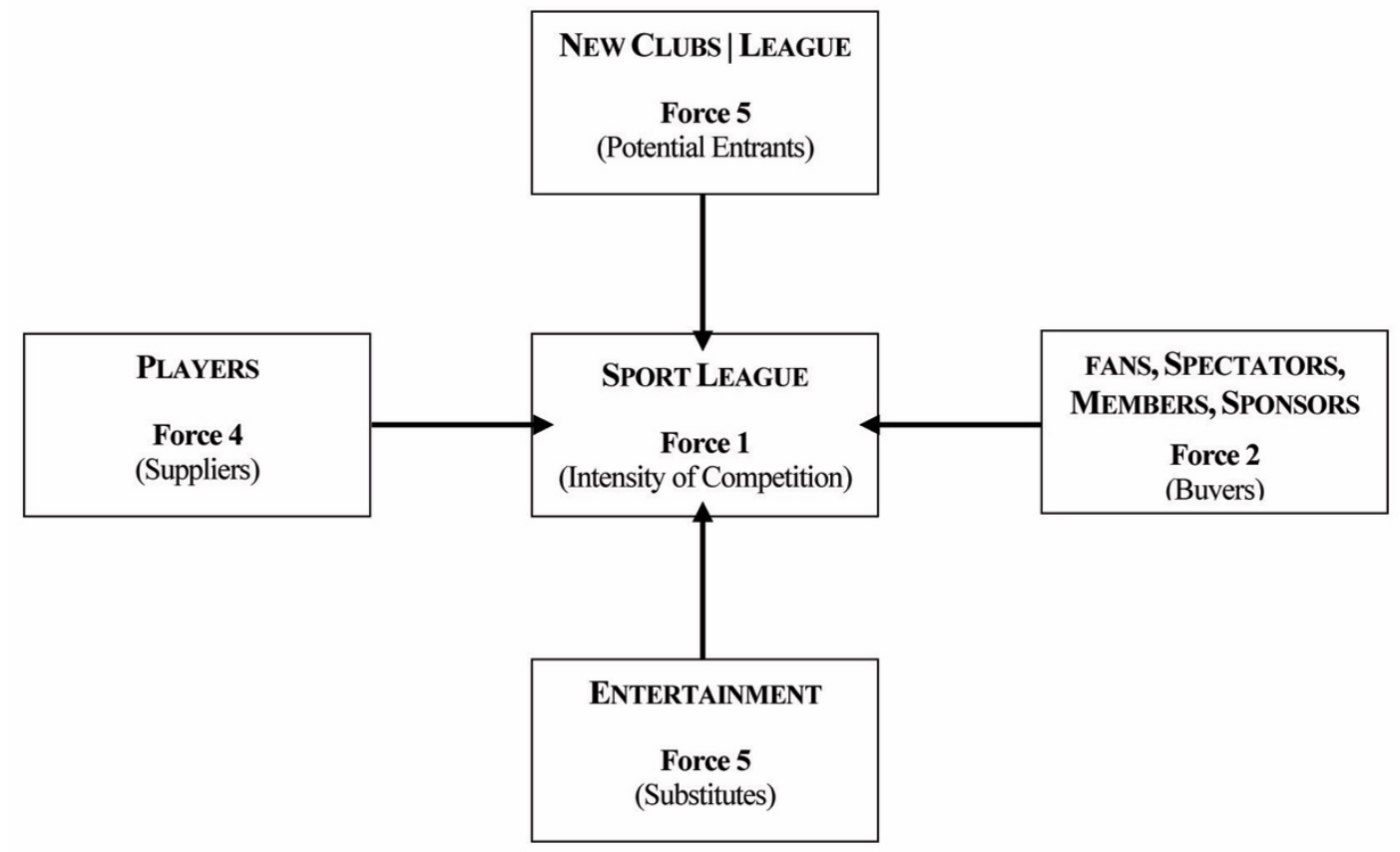

Figure 3. Porter's model in a sports club

Source: Masterman (2014).

Examining market research and utilising information systems are the fifth processes. This stage understands that the marketing research is conceived for guaranteeing that decisions made in relation to marketing plan missions and goals are based on a totally understanding of the marketplace. Basically, market research in sports club seeks to answer six questions about customers in relation to their consumption of the product. Initially, sports club need to know (i) Who the customers-fans are, (ii) Why they buy a specific sport product, (iii) When and (iv) Where they buy the product or service, (v) What that consumption entails in terms of pre-and post-event activities and (vi) How customers-fans use the product for establishing a complete specification of their profiles (Mastermann, 2004; Shilbury, 2009). Concerning about marketing information systems (MIS), its function is compiling the information and, then, integrating, analysing and providing support to guide sports marketers for use in decision making. Information collected through market research and organised into meaningful data sets provides the foundation for sports marketers to determine marketing strategies. In other words, the information 
provided by MIS helps sports marketers refine and develop their sports, to know where and when to offer them and to what age groups and at what times (Ratten \& Ratten, 2011; Ratten, 2016).

For Fullerton (2007), from data and information from market research and MIS, Porter's model and outside environment reports are structured and opportunities and threats analysis as well as from inside environment a strengths and weakness analysis. These four variables provide real situations related to sports club business and factors which influence the customers-fans' behaviour. Therefore, the six process aims to design a SWOT matrix analysis to provide a such structure (Rundh \& Gottfridsson, 2015): (i) strengths are resources, skills or other advantages relative to competitors and market; (ii) weakness are restriction or scarcities in resources, skills, and capabilities that limit a sports club's effectiveness in relation to other competitors; (iii) opportunities are the larger favourable situations in a sport's environment; (iv) threats are larger unfavourable situations in a sport's environment. However, the SWOT has the function, not only, to prepare a list of variables (see figure 4), but from intersections opportunities and threats with strengths and weakness aims to develop a set of strategy describing through an action plan, how sports club will deal with new situations and challenge regarding actual and future businesses, sport markets and customers-fans. Each intersection produces at least one strategy.

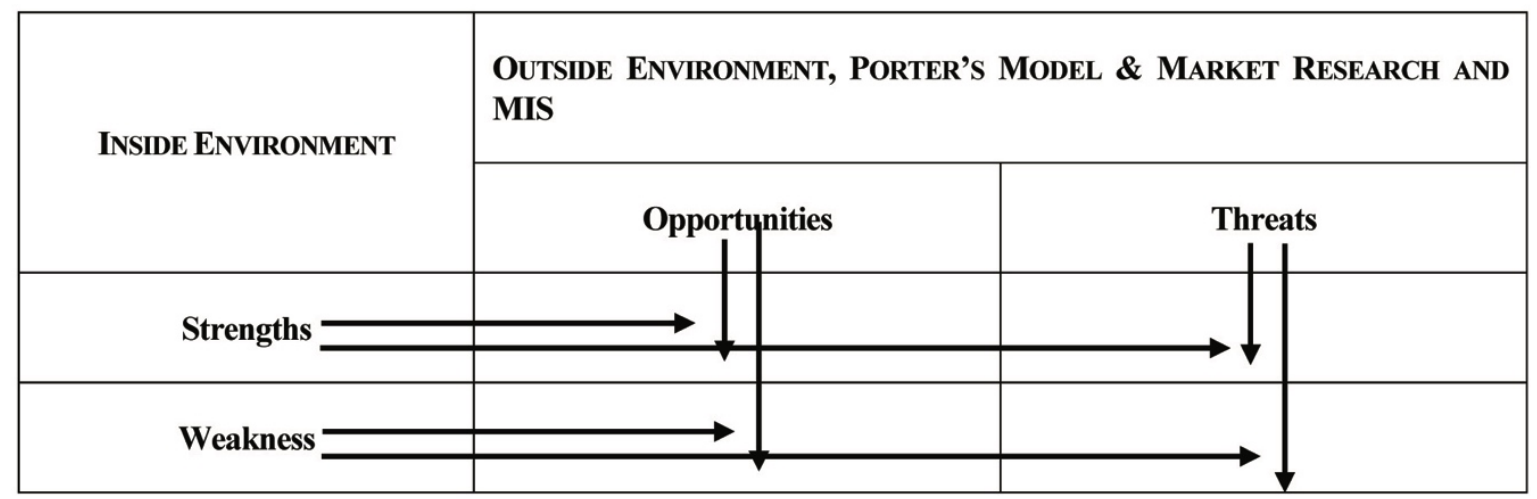

Figure 4. SWOT model

Source: Authors.

\subsection{Goals \& Fan's Audience}

Defining goals and objectives are the first process of this second level. Sports club goals to refer a board aims that sports clubs strive to pursue. Shilbury (2009) presents four goals to the sports club, as ensuring financial viability, expanding participation, bringing up the number of members and encouraging public interest in the sport. In general, objectives must: be measurable; represent the performance goals as well as the results that the sports club wants to achieve in sports area; be a guide to pursue the performance or results of sports; be proper; have a period of time; be goals practical; be evident; start with an infinitive verb for expressing an action; be familiar to all stakeholders within a sports club and the area. Objectives represent "what will be done or accomplished" in the sports area, and "how is it will be done" with regards to Sports Marketing Mix. In summary, the objectives should be defined by the acronym SMART: S-Specific, M-Measurable, A-Achievable, R-Realistic and T-Timetable.

The second and third processes involve selecting the appropriate target audience and defining the target customers-fans' profile. In identifying a segment, sport marketers must consider: (i) if a market segment is substantial enough to justify new marketing actions; (ii) if its size and attractiveness in terms of financial resources are measurable; (iii) if sports club may access this segment, and have resources to approach it; (iv) if the segment is different than others. Then, target audience includes selecting choosing a segment to prepare and deliver a specific Sports Marketing Mix to meet customer-fan's needs and expectations (Fullerton, 2007). By the large, five groups of variables are considered for selecting a target audience: (i) Geography: relate to area or location, city size, the urban and rural areas and area climate where sports club want to develop activities, including international areas; (ii) Demography: refers to gender, age, income, education level, etc; (iii) Psychographics: focus on attitudes, interest and opinions that guide behaviour a sport product, service or event; it may be derived from customer-fan stress-reduction, core values, level of sociability, lifestyle, personality type, attributes associated with a sport team brand, etc; (iv) Benefits: take into account the different level of benefits 
relate to products and services, i.e., a fan may choose to attend a football match not because they like the sport, but because a friend is following in.. Thus, benefits are based on opportunities for social interaction in sports events; (v) Behavioural: refers to frequency and complexity of product or service usage, i.e., how many times a customer-fan participates in or watches a sporting event. Then, sports club may classify customers-fans in respect to usage patterns, broad categories are established including non-user, light user, medium user and heavy user. However, it worth mentioning that all level of segmentation needs to ponder all variables of customer behaviour collected from the market and MIS (level 01), such as customer's culture, customer's sociability, customer's personal life and customer's psychology. Because, these attributes support to sports marketer defining the specifically the target audience of Sports Marketing activities (Yoshida \& Dames, 2010; Piipponen, 2011).

Positioning is the fourth process. Positioning involves the act of leading up to sports club benefits to the target audience. The goal is get up to the individual's mind (cognition) and making them thinking and reflecting around of possibilities of "buying" the sports club benefits. The focus on attractive benefits to overcome the competition benefits in their mind. Whatever is different in the offering of the sports club needs to be important and distinctive value proposition in order for the customer to consider the offering. Regarding sports arena, sports marketers and promoters regularly try to effectively position their good and/or service in the mind of a more and more shrewd customer. Moreover, given that customer liking is in a constant state of change, the positioning process demands, even more, creativity, responsiveness, and acumen. Given that, the sports marketplace is so pushful and dynamic in relation to change, which sports marketers should not only recognise the shift but also be strategically prepared to answer to it soon (Ferrand \& McCarthy, 2009). Then, the promotion of the Sports Marketing Mix is the tool to offer the communication of the value proposition to a target audience by means messages with the purpose to fix benefits in the individuals' mind. Regarding improving the understanding around the positioning was designed the figure 5.

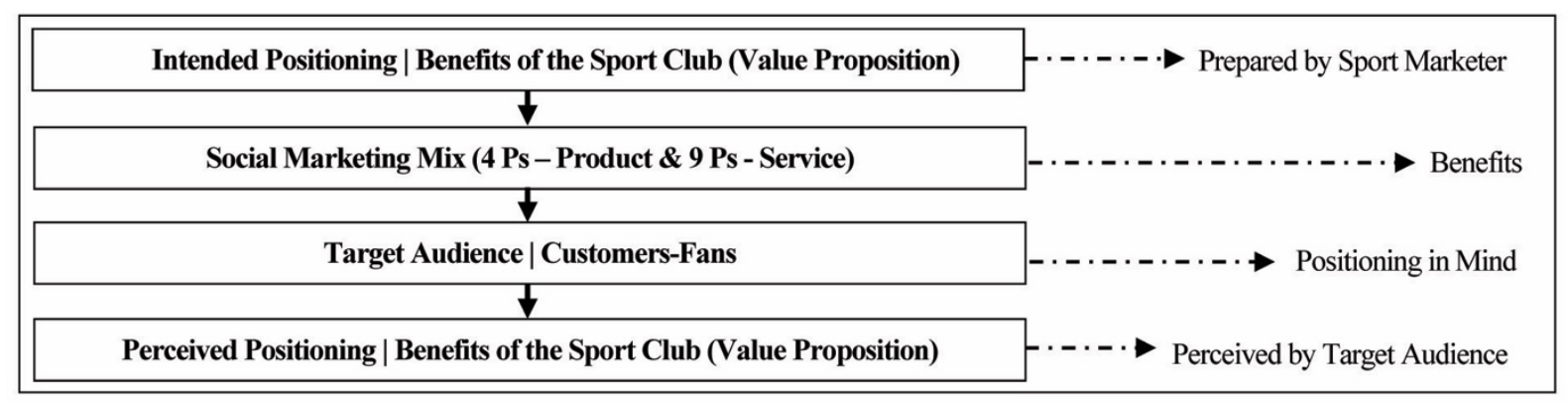

Figure 5. Positioning processes

Source: Authors.

\subsection{Sports Marketing Mix}

Marketing mix is the tactic to set the strategies into sports club customer-fan oriented. These tools may be handled at any time with the purpose of fit 4 Ps (product, price, place and promotion) for tangible products as well as 9 Ps (traditional 4 Ps, people, process, physical, performance and programs) for intangible products, as services, matches and events. The first "P" is the product. Products may be tangibles and intangibles (services). Sports products include goods, services, events, information and media, places, people and ideas. Hence, the product is understood as aught that can be offered to a market appreciation, purchase, use or consumption that might satisfy an expectation or a need. Furthermore, a product is a problem-solver in that is bought because of the benefits offered. Essentially, customers-fans buy benefits, not the products. In sport, the product is easily noticeable, but the performance of the central product is something over which the sports marketers have no control. Considering playing of the match as the central product, and all the associated processes, such as food, beverage, merchandise, half-time entertainment, video screens and the facility itself as product extensions. Even matches (or games) receiving great audience and revenues, such Barcelona vs Real Madrid, do not always guaranteed quality contest. Even with great players in the game (or match). It is at this point that resemblances are noticed between the relevance of performances service supply and quality performances extensions. Often, most product extensions have a component of service supply, and thus, performance is relevant (Mason, 1999; Shilbury, 2009). Therefore, product extensions have the capacity to ensure that spectator at the football has an 
enjoyable day irrespective of on-court results. Under these circumstances, sport tangible products as clothes, shoes, souvenirs, facilities, food and beverages, etc; sport marketers can guarantee and ensure a quality pattern customers-fans, yet, sport tangible product as events and services they cannot vouch for quality levels, because depend of stakeholders such: players, professionals, sponsorships, fans and weather. In general, sport product: (i) is invariably impalpable and subjective; (ii) is inconsistent and unforeseeable; (iii) marketing emphasis must be introduced on product extension instead of the central product; (iv) sport is usually publicity consumed, and customer's expectation is invariably influenced by social facilitation; (v) sport is both customer and enterprise product; (vi) sport evokes empowerment, personal identification, and emotional attachment; (vii) sport has almost universal appeal and immerse all elements of life, that is, geographically, demographically and socioculturally (Fullerton \& Merz, 2008).

The second "P" is a price. Pricing, as a process, may merely be described as setting and adjusting a price charged to a customer-fan in exchange for a good and/or service. Pricing a product or a range of products properly is of extremely relevant to a sports club. The level of pricing characterises how many customers are encouraged to buy the sports club's products and/or services. Pricing strategies are guided in relation to other parts of the Sports Marketing Mix, for example, product mix, value proposition, brand sponsorship, place dependence, promotion mix, professional skills, physic facilities, technologies in processes, sports club position in leagues, talented players in the team (Lionel Messi, Cristiano Ronaldo, etc.) and customers-fans' loyalty (members, light, medium and heavy users). The customer adoption process involves making potential customers aware of the product, giving them information, let them evaluate the product, then getting them to trial and finally commit to it and therefore become loyal. In general, the strategic pricing process incorporates both external environment (e.g., competitors' pricing behaviour) and internal environment (goals and objectives). This will enable the sports marketers to create a pricing strategy beyond the short-term future of the sports club (Masterman, 2004; Fullerton, 2007). There are eight processes which a sport marketer need to draw attention (Masterman, 2004; Bernstein, 2015): (i) determine pricing goals: it recognises the influence that price has on customer-fans' perceptions of the good and/or service; (ii) identify market sensitivity to price: how sensitive customers-fans are to a modification in price is substantial in determining an extent within which the final price may be set; (iii) estimate the cost-volume-profit relationship: it estimates selling prices, volume of sales, unit variable cost, total fixed cost, i.e., the break-even analysis; (iv) determine pricing strategies of major competitors: how competitors are positioned in terms of their relative prices; (v) determine constraints on pricing behaviour: it knows law as well as regulations related to pricing behaviour; (vi) determine constraints by other marketing mix variables: it recognises the impact of variable of the marketing mix; (vii) determine time dependence: it involves supplying and demanding, as well as discount of price in low-demand; (viii) determine final price: is based on cost, competition, demand or a combination of all three. Thus, pricing is often decided by what the customer will bear rather than by full cost recovery.

The place is the third "P". Place or distribution decisions relate to how sports marketer get the good and/or services to the customers-fans or how sports marketer get the customer to its good and/or service. It would not make sense to have a great good and/or service if customer-fans could not access it. These decisions typically relate to getting the goods to the customers-fans when they want it and where they want it. Then, to make products and/or services easier for its customers to attend matches, for example, the sports club a deal with the local transportation authority to include ride fares on the city's light rail system with ticket plans, parking, etc (Greenwell, Fink \& Pastore, 2002). Places decisions in Sports Marketing require (Shilbury, 2009; Sawyer, Judge \& Gimbert, 2015): (i) location: where will sports club hold matches, events or activities? (ii) facilities: what facilities will sports club use or will be available to customer-fans? (iii) access: where will sports club products will be available? When will sports club hold your matches, events or activities? (iv) duration and time: what time the matches, events or activities are will happen? How long will sports club match, events or activities be? (v) distribution agents: will sports club use wholesalers, retailers, media, etc., to deliver its products and/or services to customer-fans? (vi) inventory: how sports club manage its inventory, as ticketing, memberships, registrations, security, etc.? Sport as service emerges four elements which a sport marketer requires planning: (i) facility: production and consumption of sport products and/or services taking place in the facility, as stadium, stores, point of sale, parking, etc., it takes into account easy access, comfortable structure, internal communication and immaculately clean; (ii) physical evidence: sport facility design, promotion material and advertising and service provision; (iii) process: it involves delivering good and/or service to customer-fans, some processes are visible (e.g., buying tickets) and others are not (e.g., cooking a food); (iv) people: who those which will performance the processes. Finally, the marketing channels have also functions in relation to exchange process between sports club and customer-fans: transportation and storage, communication of information via advertising and publicity, personal selling, sales promotion, feedback (marketing research), financing and 
services such as installation, customisation and repair. Stadium, stores and Internet are placed which sports club deliveries their value proposition, interacts with their customer-fans and, still, provide satisfaction to them.

The next "P" is the promotion. For Smolianov \& Shilbury (2005) and Maltese \& Danglade (2014), promotion decision relates to communication with target customers-fans. In sports promotion decision, can relate a variety of goals such creating awareness, stimulating demand, encouraging product, service and experience, and getting and retaining loyal (or members) customers-fans. In general, the promotional decision requires understanding five elements: promotional objectives, promotional budget, message content, promotional strategies (advertising, public relations, publicity, sales promotion, personal sale, product placement, digital marketing, direct marketing, customer relationship management, advertainment, buzz marketing, etc.) and media selection (television, radio, Internet-social networks, YouTube, etc., newspaper, magazine, billboards, etc.). Promotion is a fundamental and vital part of the sports experience, thus, how the sports marketer and promoters handle the promotion mix will be crucial to the success of the event, and even the long-term viability of the sport. Piipponen (2011) states that the real consequence of the communication process is provoking a certain encouragement to the event. In most instances, it is to incline the target audience towards the product, service, and experiences embedded in the message. However, sports marketer need to concentrate the promotional program considering four categories of customers: indirect customers, light users, medium users and heavy users (e.g., membership). Promotion mix, known as Integrated Marketing Communications (IMC), consists of use of tools to promote an institutional image; increase sales in ticketing (physical or virtual); increase sales in products and/or services; promote a new good and/or service; increase numbers of members; promote a new player or talent; promote a new sponsorship; promote an important and a decisive match; share customer-fans' feelings; promote an event, as a concert music, in its arena; promote the governance and social responsibility; and promote relevant announces, in general.

Physical is the fifth "P". Physical represents the atmosphere created by sports marketers for receiving fans for sharing an experience of supporting their team in a match, an event or an activity. The physical evidence should be appellative, attractive and promote fans' energies and feelings, for scaring opponent's teams. Hence, physical representation, if unique and engaging, can "tangilise" the facility, giving it brand identity and inducing strong cognitive images. Hence, the sports marketer should offer the sports product with physical evidence (Greenwell, Fink \& Pastore, 2002). Two elements require being developed for introducing an appropriated physical evidence to customer-fans (Sawyer, Judge, \& Gimbert (2015): (i) sports facility design: is the most tangible and visible physical evidence sports marketers can have for their products. The name of the facility can be displayed and marketed as the place where exciting events occur. In addition, banners, photographs of statues of sporting heroes can decorate the inside and outside and, still, inner walkways of the facility. Hight-tech scoreboards (as big screens) showing sports club's achievements and victories, as well as its history and tradition, may evoke feeling and enhance the tangibility of the event and atmosphere; (ii) promotion: is possible using instant communication for promoting products and/or services using social networks and sports club website to interact with fans before and during the matches, events or activities inside the arena and creating games to entertain the audience using sponsorship products and services. According to Masterman (2004) and Shilbury (2009), it is possible launching sports club's products and services and broadcasting customer-fans' experience encouraging customer of posters, merchandise, advertisements and several souvenirs. Thus, physical refers to create a favourable environment in arenas or stores using the tradition, history and gotten conquests to encourage customers-fans to invest time, energy and money to buy products and/or services as part of fans-community.

The sixth "P" processes. The processes are understood as the activities or tasks which are visible and non-visible. Being a service - a match, an event or a retail - requires the definition of the processes to produce and deliver benefits and value to customer-fans. Processes in service are, also known, as service design - considering Design Thinking perspective; or value chain. The process is the method as well as the sequence of actions in the performance of the services (Moore \& Levermore, 2012). If a process is badly projected will create a delivery slow, bureaucratic and ineffective; and after will result in dissatisfaction of target audience around the service performance. Because that, if a process is not well aligned and designed can produce low performance of the service of the frontline team, before long the efficient and effectively of the service can be compromised, as effect of lack of synchrony between what has been offered and what has been "sold", in terms of benefits, to target customers-fans. The processes must be planned and designed continuously in seeking of (Ratten, 2012, Rundh \& Gottfridsson, 2015): (i) reducing failures extinguishing possible steps that do not "add value" to target customers-fans; (ii) introducing processes-orientation in order to produce the best service possible in addition to increase productivity and quality; (iii) finding out the average time per activity cycle; (iv) managing physical evidence visible to customers-fans, such as facilities, receptions, parking, ticket machines, seats, small restaurants, people, etc. (v) identifying failure points and think about all that could be wrong; (vi) and preparing 
flowchart or blueprint to document the service processes produced in a match, an event, an activity, store, and others. The goal of the process is clarifying all range of steps and progression required for delivering a good and/or service appropriate to customers-fans.

People is the seventh "P". In a match, an event, an activity, etc., people (or professionals) are essential and crucial to get the great performance. In the view of customers-fans, the staff team of service represents the provider of services. The assessing the quality of the match, event and activity are based on the customers-fans' interactions with the frontline team. The silks of the staff team in Sports Marketing must be lined up in order to (Piipponen, 2011; Collignon \& Sultan, 2014): (i) it has knowledge or domain around of the whole service value chain processes from the begin to the end in order to attend the service performance expected by the customers-fans.; (ii) control conflicts between sports club, sponsorship and customers-fans with customers-fans, in specifically, the team of frontline; (iii) and respect the moral and ethical patterns related to their commitment and responsibility. Thus, the skills in Sports Marketing increase the potential of success of given match, event or activity, since are the professional who will meet, interact, engage and understand the customers-fans and, then, communicate about the value proposition and benefits to customers-fans. Professionals' skills make the difference in a match, an event or an activity, because they produce the service, thus a sports club need to: (i) hire professionals to get performance in service processes with purpose of leverage their skills in favour of matches, events and activities; (ii) provide support, consistent infrastructure, guidelines, training, etc.; (iii) and develop skills professional for Sports Marketing, as teamwork, knowledge around the processes, etc. Therefore, in the customers-fans' view, a qualified staff team guarantees a comfortable and effective service and, consequently satisfaction to them.

In the entire Sports Marketing match, event, activity, etc., performance index must be measured, in view of the monitoring and adjustment of some processes. Then, the eighth "P" is the performance, since is required developing quantitative and qualitative index-financial and non-financial and the implication that pervades the sports club competence while planner and organiser of matches, events, activities, point of sales, such as: ethics pattern, respect customers-fans and respect their free choices (since not all customers-fans want the same thing related to good and/or service). In other words, the goal is measuring the ability of the provider to deliver the benefits in a given event. Lovelock \& Wirtz (2011) describe five dimensions for assessing the service quality, which can be lined-up to Sports Marketing: (i) tangibility: the physical appearance (facilities); (ii) reliability: performance accuracy; (iii) responsiveness: quickness and supportiveness; (iv) security: credibility, competence, certainty, and proactivity; (v) empathy: readily accessible, communication and understanding of customers-fans' needs. The quality and performance ensure the value proposition as well as benefits to customers-fans, because are fans who define the quality standard in Marketing. Wherefore, it is worth mentioning the six gaps in service quality to be useful to sport marketers who prepare sport events: (i) difference between what the sports marketer considers that the customers-fans expect and their actual needs and expectations; (ii) difference between sport marketer's sense about customers-fans expectation and quality standards delivered in a given sport event; (iii) difference between performance promised and the performance delivered; (iv) difference between what sport marketer promotes and what they delivery; (v) difference between what is actually delivered and what customers-fans realise as delivered; (vi) difference between what the customer-fans expect to receive and their perceptions about what sport marketer delivered.

The last "P" is the program, i.e., which reflects all activities involved in the sports marketer's efforts to achieve the target customer-fans in a sports match, event or activity. It is an action plan encompassing the entire steps of levels 1, 2 and 3 previously presented. This document must describe each process of Sports Marketing plan. Sports Marketing plan helps professionals to get performance and quality for guaranteeing benefits to customers-fans, with purpose of mapping deficient processes and suggestion solutions; introducing the customers orientation in the entire circle to ensure the benefit; prioritising actions that achieve the customer-fans' satisfaction; controlling the performance of process to guarantee great results; ensuring the service performance and removing gaps which are affecting the performance as well as customer-fans' dissatisfaction; assessing the staff team at work with the target customers-fans and their expertise; and handling the marketing mix to achieve the mission, goals and results of the Sports Marketing plan in view to promote feelings, as happiness, emotion; and experiences to customers-fans in order to keep healthy relationships. The program is a sort of action descriptive document to aim an intention plan to future achievements (Chadwick \& Thwaites, 2005; Fullerton, 2007; Shilbury, 2009).

The term sponsorship is becoming unfashionable with a development that sees more use of the word "partnership" in an attempt to depict a great relationship and perhaps even increased competitive advantage. Sponsorship is a business relationship between a provider of funds, resources or services and an individual, event 
or organisation (e.g., sports club) which offers in return some rights and association that may be used for commercial advantage. There are various levels of status available at a match, an event and an activity and these relate to the rights that they receive as a result of their association with the event (Amorim \& Almeida, 2015). These rights consist of a bundle of benefits that can offer the use of certain titles and more often than not these titles are an acknowledgement not only of the status that the sponsor has with the event but they are also indicative of the relationship they have with other sponsors at the event. Here are the levels of status that are available (Masterman, 2004; Smolianov \& Shilbury, 2005; Shilbury, 2009): (i) title rights (or sponsor): a status that involves the sponsor in the title of the event, league or championship; (ii) naming rights: these rights are associated with physical structure (or facilities) and more commonly in long-term agreements whereby a building such as a stadium or arena; (iii) supplier rights: it is a sport organisation which produce and provide sports uniform and various sports merchandise; (iv) selling channel: it is an organisation responsible for selling tickets to matches, events or activities to customer-fans; (v) financial channel: organisation which carry out financial transaction of selling tickets; (vi) accommodation partnership: hotel which accommodate players as well as team staff when team plays in another city; (vii) beverages partnership: companies which commercialise beverages or soft drinks inside of arena or stadium; (viii) food partnership: organisations responsible for selling foods inside of stadium; (ix) people outsourcing partnership: companies provide professionals for developing all service chain processes from begin to ending of match, event or activity, supporting fans inside of arena; (x) communication channel: companies responsible for broadcasting as well as promoting information, announces and products and/or services inside and outside or arena and other medias; (xi) athlete sponsor: companies which sponsor specifics athletes in the team; (xii) master sponsor: companies associate its names on the team uniforms; (xiii) and marketing companies: which plan and developing market strategies for a sports club, as a consulting companies to support sports club marketing actions.

\section{Final Considerations}

The Sports Marketing may appear at first to be close to orthodox marketing. However, Sports Marketing has no distinction of another sort of orthodox marketing. For example, the sports product is usually highly inconsistent as well as unforeseeable; for this reason, is not possible to predict the result of a sporting match or monitor the performance of a sports experience. In many other enterprises, the failure to guarantee the quality of a product would be disastrous. Equally, another significant difference is that few products and/or services can encourage the emotional participation and personal identification that sports experiences. For triumphing in Sports Marketing, it is necessary to understand marketing principles as well as the sport as experiences or events, also the sports market and sports customer-fan. Sports market describes outside and inside environments and Porter's model; sports customer-fan characterises through market research and IMS how customers-fans' behaviours. Therefore, when sports marketers gather these four data sources and, then, identify strengths, weakness, opportunities and threats and, after, design strategies to respond to market and customers-fans, they are concluding the first process group, which is named as a diagnosis of the situation. In other words, sports marketers have reported around what the sports market demands and what customers-fans require. It is up to sport marketers and marketing team using their skills to provide adherent strategies to market and customers-fans.

Having in their hands the report of diagnosis of the situation, sports marketers start to design the goals in relating to indexes and results and objectives expected by the main stakeholders: customers-fans, sponsors, managers, etc. Establishing the target segments using criteria as geography, demography, psychograph as well as behavioural; and considering the customers-fans characteristics with regarding cultural, social, personal and psychology. Then, when sports marketers understand what the customers-fans behaviour and define with accuracy their target audience, it is possible suiting special benefits, value propositions, products and/or services lined-up to their expectation. Knowing the target audience and the customers-fans behaviour, it is up to sports marketers to take to the market and customers-fans the brand and benefit positioning designed by the sports club. This second process group corresponds to goals and fan's audience. Thus, these authors believe that these two firsts group of processes are fundamentals for following to the next step, it means, handling available resources the tactics from the sports club, because marketing was created for understanding and satisfying customer is at the centre of notions of good and service quality regardless of sort of the customer.

The three group the process will be that one which will require creativity, innovation and integrations of elements for preparing an appropriate product, service and benefit to customers-fans. Sports Marketing mix requires an immersion on the 9 Ps because they will model what a sports club intends to offer to market and customers-fans. The 9 Ps corresponds to structure the benefits in relating to the product (or service), price, place (facility), promotion, physical (atmosphere), process, people (or professionals), performance and program 
(step-by-step plan). At this moment, which sports marketers define and establish how they will offer the sports benefits in terms of resource, capacity as well as competence considering sponsorship and partner skills as supporting them for design the appropriate activities and tasks in the Sports Marketing mix. These authors recommend ongoing of planning an iteration for finding out eventual discrepancies among 9 Ps to enhance the offer. This group the process has, at the last step, it means, developing index and reference parameters from customers-fans' feedback for increasingly the benefit standard expected from them. Sports Marketing has as principle improving the process of exchange between sports club and customer-fans in order to guarantee satisfaction to both sides. These Sports Marketing framework aims to available one additional alternative to sports marketers planning, implementing and monitoring an action plan focused on market and customer-fans to provide them with an unbelievable experience reinforcing the brand and image power to ensure the sports club sustainability.

\section{References}

Amorim, J. G. B., \& Almeida, V. M. C. (2015). The Effect of Simultaneous Sponsorship of Rival Football Teams. Brazilian Administration Review, 12(1), 63-87. https://doi.org/10.1590/1807-7692bar2015140059

Bernstein, G. (2015). The Principles of Sports Marketing. Illinois: Sagamore, Publishing.

Blumrodt, J., Desbordes, M., \& Bodin, D. (2013). Professional Football Clubs and Corporate Social Responsibility. Sport Business and Management, 3(3), 205-225. https://doi.org/10.1108/SBM-04-2011-0050

Chadwick, S., \& Thwaites, D. (2005). Management Sport Sponsorship Programmes: Lessons from a Critical Assessment of English Soccer. Journal of Advertising Research, 45(3), 328-338. https://doi.org/10.1017/S0021849905050312

Clark, J. (2011). Changing the Game: Outlook for the Global Sport Market to 2015. PricewaterhouseCoopers (PwC).

Retrieved from http://www.pwc.com/gx/en/hospitality-leisure/pdf/changing-the-game-outlook-for-the-global-sports-market -to-2015.pdf

Collignon, H., \& Sultan, N. (2014). Winning in Business Sports. ATKeaney Report. Retrieved from https://www.atkearney.com/documents/10192/5258876/Winning+in+the+Business+of+Sports.pdf/ed85b64 4-7633-469d-8f7a-99e4a50aadc8

Ferrand, A., \& McCarthy, S. (2009). Marketing the Sports Organisation. Building Networks and Relationships. London: Routledge.

Fullerton, S. (2007). Sports Marketing. Michigan: Eastern Michigan University.

Fullerton, S., \& Merz, G. R. (2008). The Four Domains of Sports Marketing: A Conceptual Framework. Sports Marketing Quarterly, 17(2), 90-108.

Greenwell, T. C., Fink, J. S., \& Pastore, D. L. (2002). Assessing the Influence of the Physical Sports Facility on Customer Satisfaction within the Context of the Service Experience. Sport Management Review, 5, 129-148. https://doi.org/10.1016/S1441-3523(02)70064-8

Kosík, M. (2011). Marketing Strategy in Connection with Sport. Innovative Marketing, 7(2), 92-98.

KPMG Report. (2014). Business of Sports: Shaping a Successful Innings for the Indian Sports Industry. Retrieved from http://www.smri.in/wp-content/uploads/2015/02/Business-of-Sports-KPMG.pdf

Maltese, L., \& Danglade, J. P. (2014). Marketing du Sport et Événementiel Sportif. Paris: Dunod.

Mason, D. S. (1999). What is the Sports Product and Who Buys it? The Marketing of Professional Sport Leagues. European Journal of Marketing, 33(3/4), 402-418. https://doi.org/10.1108/03090569910253251

Masterman, G. (2004). Strategic Sports Event Management: An International Approach. London, UK: Elsevier Butterworth-Heinemann.

Moore, N., \& Levermore, R. (2012). English Professional Football Clubs: Can Business Parameters of Small and Medium-Sized Enterprises be Applied? Sport Business and Management: An International Journal, 2(3), 196-209. https://doi.org/10.1108/20426781211261511

Piipponen, H. (2011). Enhancing Customer Relations in Team Sport Business. Thesis (Master in Marketing). Department of Marketing and Management, School of Economics, Aalto University, Helsinki, Finland.

Ratten, V. (2016). The Dynamics of Sport Marketing. Suggestions for Marketing Intelligence and planning. Marketing Intelligence \& Planning, 14(2), 162-168. https://doi.org/10.1108/MIP-07-2015-0131 
Ratten, V., \& Ratten H. (2011). International Sports Marketing: Practical and Future Research Implications. Journal of Business \& Industrial Marketing, 26(8), 614-620. https://doi.org/10.1108/08858621111179886

Rundh, B., \& Gottfridsson, P. (2015). Delivering Sports Events: The Arena Concept in Sports from Network Perspective. Journal of Business \& Industrial Marketing, 30(7), 785-794. https://doi.org/10.1108/JBIM-06-2013-0131

Sawyer, T. H., Judge, L. W., \& Gimbert, T. L. (2015). Facility Management for Physical Activity and Sport (2nd ed.). Illinois: Sagamore, Publishing.

Shilbury, D. \& Rentschler, R. (2007). Assessing Sport Management Journals: A Multi-Dimensional Examination. Sport Management Review, 10(3), 3-14.

Shilbury, D. (2009). Sport Management Series (3rd ed.). Sydney: Allen \& Unwin.

Silva, E. C., \& Mazzon, J. A. (2016). Developing Social Marketing Plan for Health Promotion. International Journal of Public Administration, 39(8), 1-10. http://dx.doi.org/10.1080/01900692.2015.1023447

Smith, A., \& Westerbeek, H. (2003). Sport Business in the Global Marketplace. New York: Palgrave, Macmillan.

Smolianov, P., \& Shilbury, D. (2005). Examining Integrated Advertising and Sponsorship in Corporate Marketing Through Televised Sport. Sport Marketing Quarterly, 14, 239-250.

The Future of Sports. (2015). Reports. Retrieved from http://www.gannett-cdn.com/usatoday/editorial/sports/The-Future-of-Sports-2015-Report.pdf

Yoshida, M., \& Dames, J. D. (2010) Customer Satisfaction with Game and Service Experiences: Antecedents and Consequences. Journal of Sport Management, 24, 338-361. https://doi.org/10.1123/jsm.24.3.338

\section{Copyrights}

Copyright for this article is retained by the author, with first publication rights granted to the journal.

This is an open-access article distributed under the terms and conditions of the Creative Commons Attribution license (http://creativecommons.org/licenses/by/4.0/). 